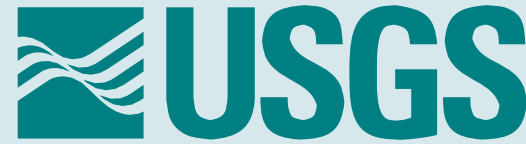

science for a changing world

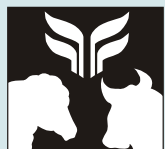

Wyoming Department of

Agriculture (WDA)

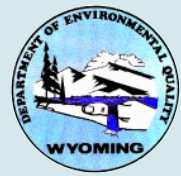

Wyoming Department of Environmental Quality (WDEQ), Water Quality Division

In cooperation with the Wyoming Department of Agriculture (WDA), the Wyoming Department of Environmental Quality (WDEQ), and the Fremont County Weed and Pest District

\title{
Pesticides in Ground Water - Fremont County, Wyoming, 1998-99
}

In 1991, members of local, State, and Federal governments, as well as industry and interest groups, formed the Ground-water and Pesticide Strategy Committee to prepare the State of Wyoming's generic Management Plan for Pesticides in Ground Water. Part of this management plan is to sample and analyze Wyoming's ground water for pesticides. In 1995, the U.S. Geological Survey, in cooperation with the Ground-water and Pesticide Strategy Committee, began statewide implementation of the sampling component of the State of Wyoming's generic Management Plan for Pesticides in Ground Water. In 1998, baseline monitoring began in Fremont County.

\section{PESTICIDES IN GROUND WATER}

Synthetic organic pesticides are used to control weeds, insects, and other organisms in a wide variety of agricultural and nonagricultural settings. The use of pesticides has helped to make the United States the world's largest producer of food (Barbash and Resek, 1996). Pesticide use, however, has also been accompanied by concerns about potential adverse effects on the environment and human health. A potential pathway for the transport of pesticides is through hydrologic systems, which supply water for both humans and natural ecosystems. Water is one of the primary ways pesticides are transported from an application area to other locations in the environment (fig. 1) (Barbash and Resek, 1996).

Pesticide contamination of ground water is a national issue because of the widespread use of pesticides, the expense and difficulty of remediating ground water, and the fact that ground water is used for drinking water by about

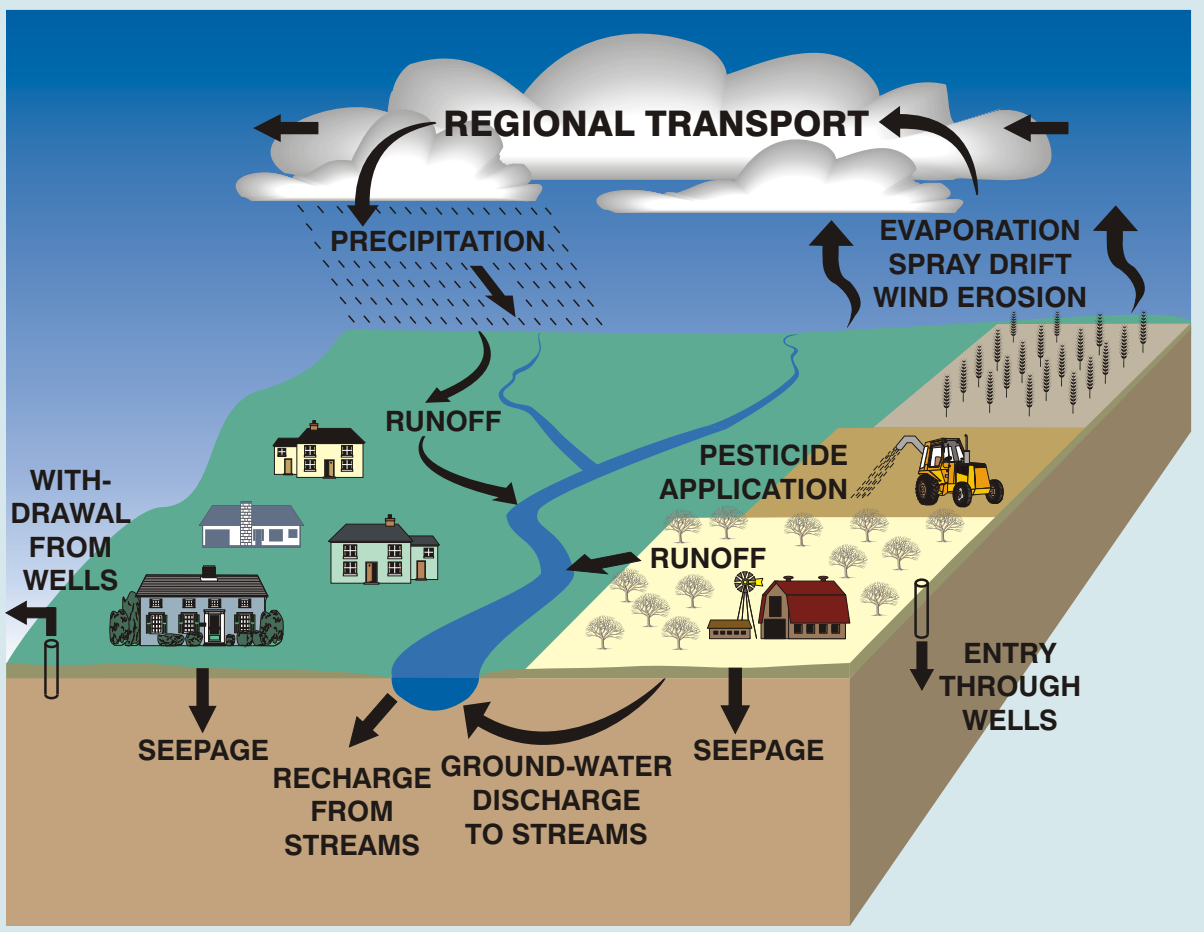

Figure 1. Pathways of pesticide movement in the hydrologic cycle (modified from Barbash and Resek, 1996).

50 percent of the Nation's population. Concern about pesticides in ground water is especially acute in rural agricultural areas where over 95 percent of the population relies upon ground water for their drinking water (Solley and others, 1998), although application rates and the variety of pesticides used may be greater in urban areas.

\section{WYOMING'S PESTICIDE MANAGEMENT PLAN}

The Ground-water and Pesticide Strategy Committee (GPSC) has developed the generic State Management Plan for Pesticides in Ground Water for the State of Wyoming (SMP) (Wyoming Ground-water and Pesticides Strategy Committee, 1999). The SMP is required by the U.S. Environmental Protection Agency (EPA) in order for organizations and individuals to continue using certain pesticides in Wyoming. The SMP includes information relating to organizations and individuals involved with the implementation of the SMP, methods of preventing ground-water contamination, ground-water monitoring, and what the responses will be if pesticides are detected in ground water.

One critical part of the SMP is ground-water monitoring. The groundwater monitoring program has two phases. The first phase involves baseline monitoring, which is an initial survey of pesticides in a county's ground water. The second phase is problem identification monitoring, which is used to gather more information about the ground water 
Table 1. Baseline monitoring for pesticides in Fremont County, 1998-99.

$[\mu \mathrm{g} / \mathrm{L}$, micrograms per liter; trace indicates pesticide detected, but at a concentration too small to quantify]

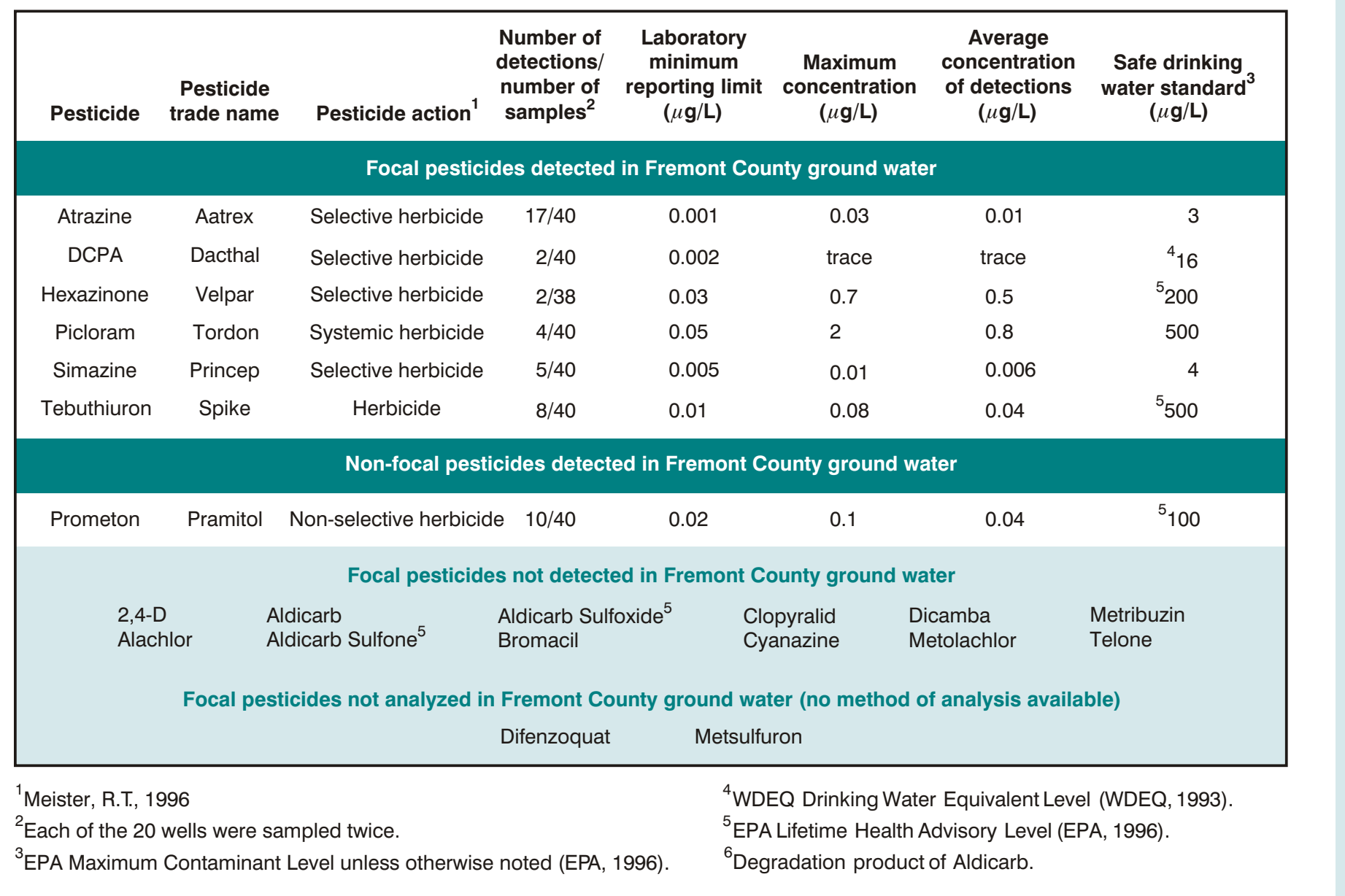

near wells with significant pesticide detections.

Baseline monitoring is prioritized by a county rank and the vulnerability of the county's ground water to pesticides.

During the development of the SMP, the GPSC evaluated each county in Wyoming to determine the potential vulnerability of the county's ground water to pesticides. Each county was ranked based on the extent of cropland and urban areas in the county, as well as

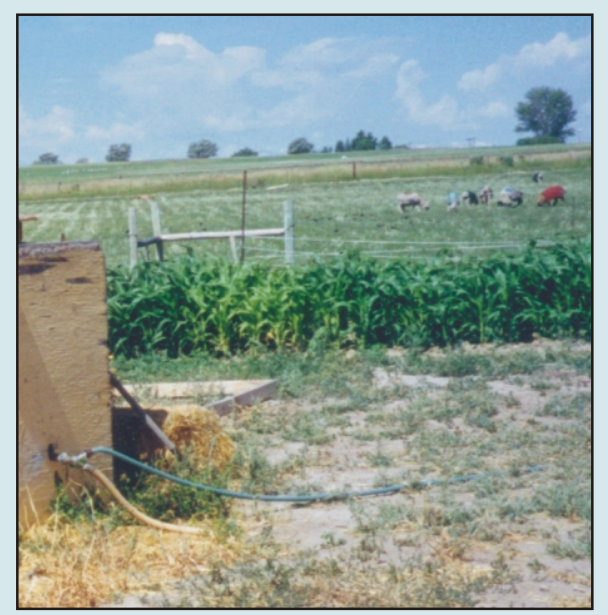

the amount of pesticides sold within the county in 1991 (Wyoming Ground-water and Pesticides Strategy Committee, 1999).

A ground-water vulnerability map was prepared for the uppermost or shallowest aquifer by the University of Wyoming Spatial Data and Visualization Center (SDVC). A Geographic Information System was used to overlay seven coverages describing hydrogeology and land use. The map produced was used to assist in the selection of monitoring sites in each county. The monitoring focuses on areas where the ground water is most vulnerable.

The GPSC selected 18 pesticides (focal pesticides) and 2 degradation products to be sampled as part of the SMP (table 1). An additional 66 pesticides and degradation products are included in the U.S. Geological Survey analytical protocol, resulting in possible detections of non-focal pesticides. Ground water from all wells in the baseline monitoring program was analyzed for the pesticides listed in table 1, with the exception of difenzoquat and metsulfuron because analytical methods were not available for their analysis.

The goal of the sampling program is to collect ground-water samples for pesticide analyses in all 23 Wyoming counties. The ground-water sampling part of the SMP began in Goshen County in 1995. Sampling in Park and Washakie Counties was conducted in 1997, and completed by 1998. In August 1998, sampling began in Fremont, Lincoln, and Laramie Counties. The sampling for these three counties was completed in May 1999.

\section{GROUND-WATER MONITORING IN FREMONT COUNTY}

The ground water in Fremont County was ranked the fourth most vulnerable to pesticide contamination in Wyoming. The vulnerability map for Fremont County (fig. 2) was created by the SDVC (Hammerlink and Arneson, 1998). Shallow alluvial and terrace deposits were identified as the most vulnerable areas in the county. 

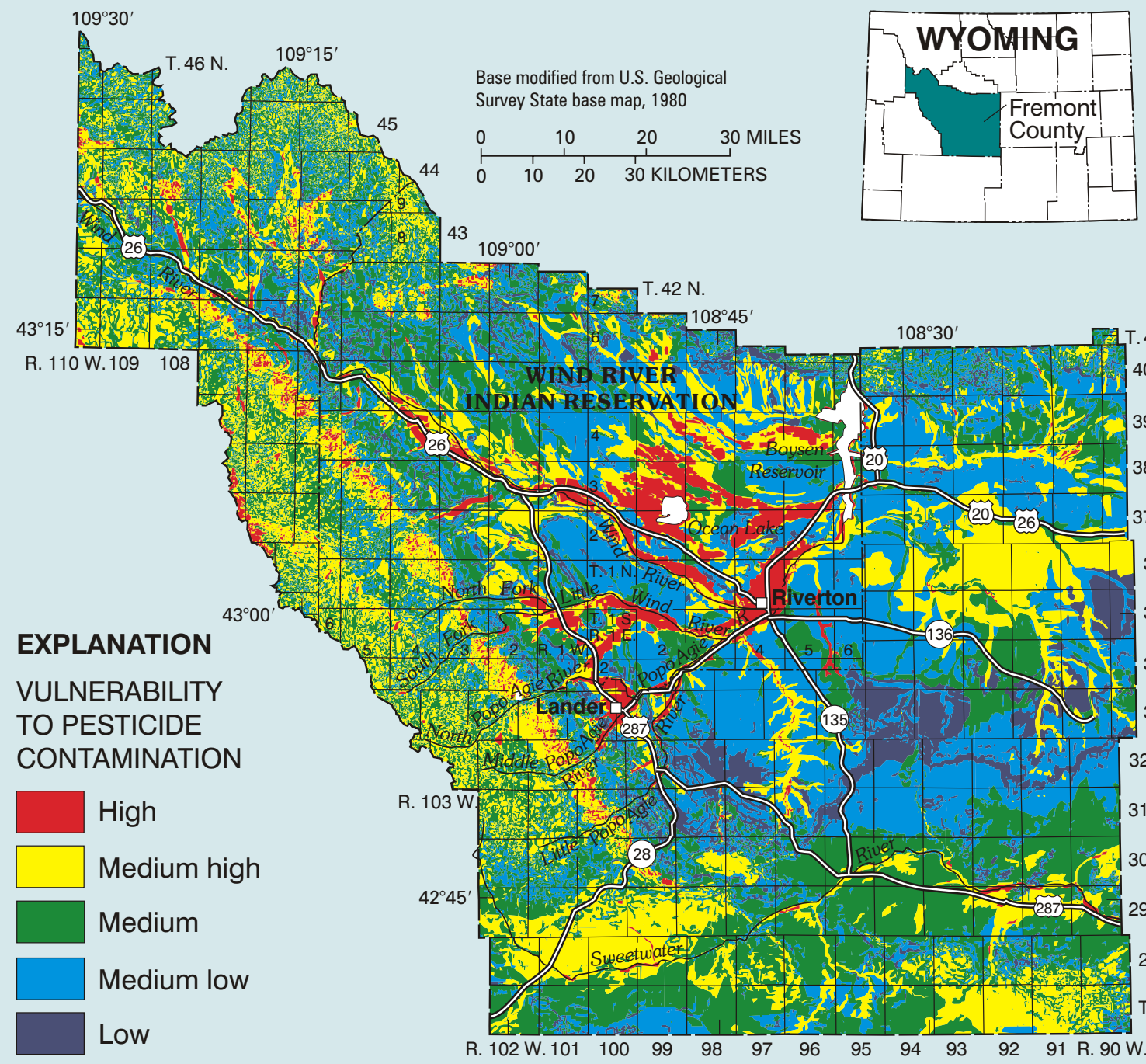
Base modified from U.S. Geologic $\begin{array}{llll}0 & 10 & 20 & 30 \\ & 1 & & \end{array}$ 43 $109^{\circ} 00$ (1)
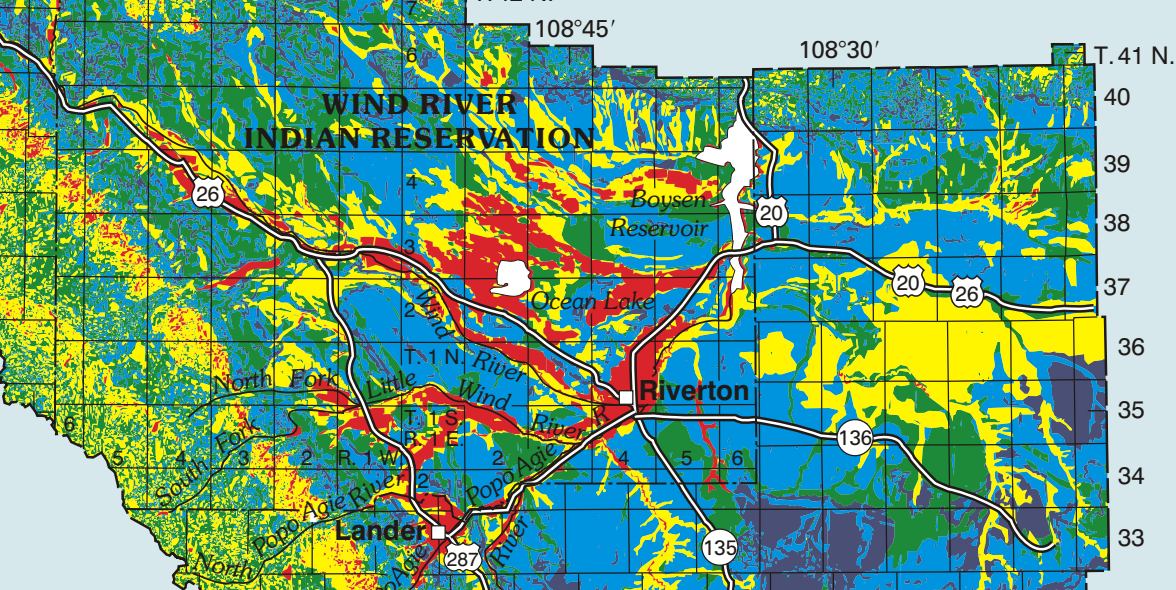


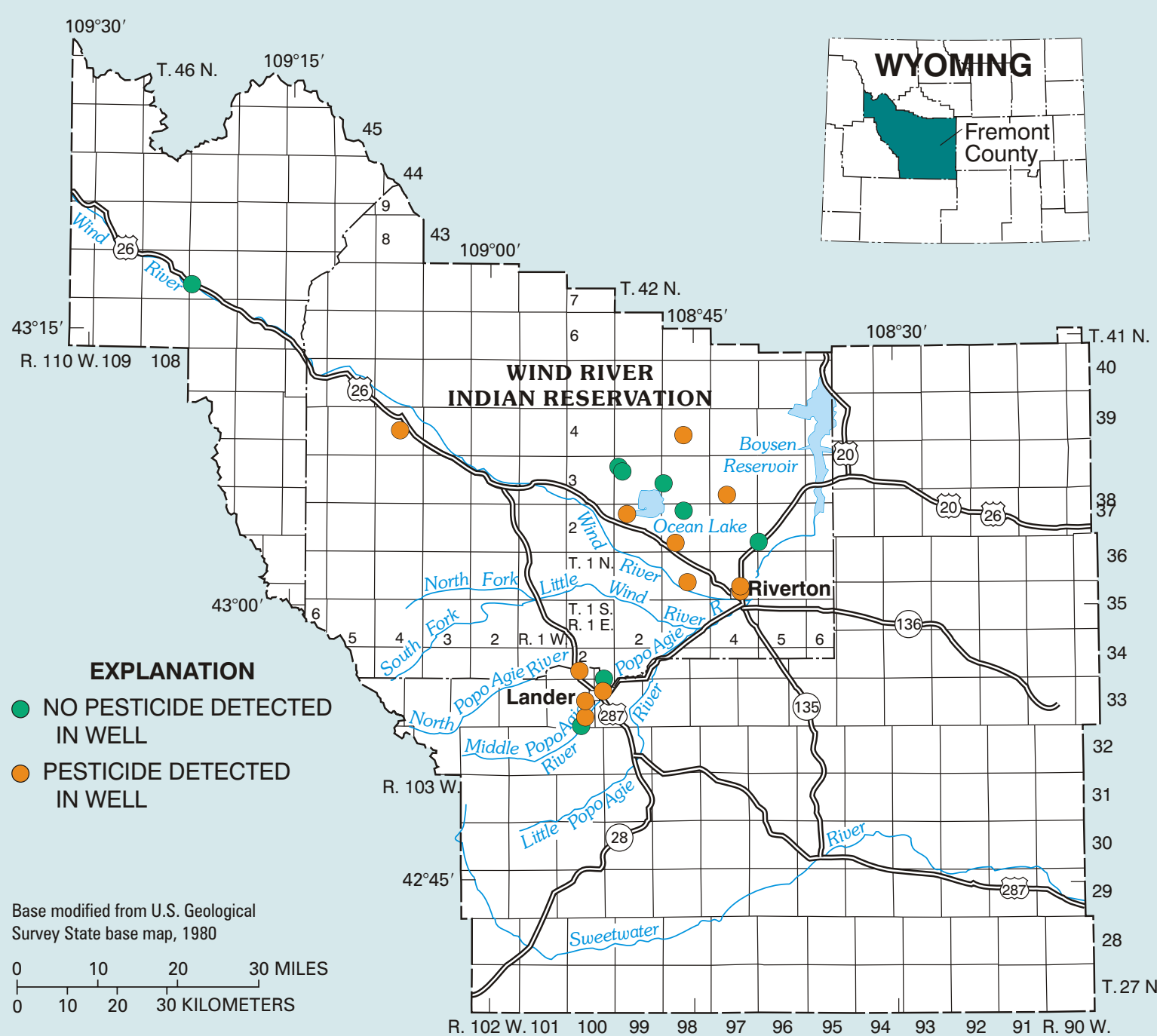

Figure 3. Location of wells sampled in Fremont County, and notation of pesticide detection in each well.

\section{REFERENCES:}

Barbash, J.E., and Resek, E.A., 1996, Pesticides in ground water--Distribution trends, and governing factors: Ann Arbor Press, Chelsea, Michigan, p. 3

Barbash, J.E., Thelin, G.P., Kolpin, D.W., and Gillom, R.J., 1999, Distribution of major herbicides in ground water of the United States: U.S. Geological Survey WaterResources Investigations Report 98-4245, $64 \mathrm{p}$.

Hammerlink, J.D., and Arneson, C.S., editors, 1998, Wyoming ground water vulnerability assessment handbook: Volume 2. Assessing ground water vulnerability to pesticides: Spatial Data and Visualization Center Publication SDVC 98-01-2, University of Wyoming, Laramie, Wyoming, variable pagination.

Mason, J.P., Miller, D.T., and Ogle, K.M., 1999, Water resources data, Wyoming, water year 1998, Volume 2. Ground Water: U.S. Geological Survey WaterData Report WY-98-2, 127 p.

Meister, R.T., 1996, Farm Chemicals Handbook: Willoughby, Ohio, Meister Publishing Co., variable pagination.
Solley, W.B., Pierce, R.R., and Perlman, H.A., 1998, Estimated use of water in the United States in 1995: U.S. Geological Survey Circular 1200, 71 p.

Swanson, R.B., Mason, J.P., and Miller, D.T., 2000, Water-resources data, Wyoming, water year 1999, Volume 2. Ground Water: U.S. Geological Survey WaterData Report WY-99-2.

U.S. Environmental Protection Agency, 1996, Drinking water regulations and health advisories: EPA 822-B-96-002.

Wyoming Department of Environmental Quality, 1993, Procedures for establishing environmental restoration standards for leaking underground storage tank remediation actions, WDEQ/WQD Rules and Regulations, Chapter XVII.

Wyoming Ground-water and Pesticides Strategy Committee, 1999, Wyoming generic state management plan for pesticides and ground water: prepared for Wyoming Department of Agriculture, Cheyenne, Wyoming, 103 p.

The use of trade, product, industry, or firm names is for descriptive purposes only and does not imply endorsement by the U.S. Government.
FOR MORE INFORMATION, CONTACT:

\section{Jim Bigelow}

Wyoming Department of Agriculture

2219 Carey Avenue

Cheyenne, Wyoming 82002

(307) 777-7324

\section{Kevin Frederick}

Wyoming Department of Environmental Quality, Water Quality Division 4th Floor, Herschler Building Cheyenne, Wyoming 82002 (307) 777-7781

\section{District Chief}

U.S. Geological Survey, WRD 2617 E. Lincolnway, Suite B

Cheyenne, Wyoming 82001 (307) 778-2931

Email: state_rep_wy@usgs.gov Internet: http://wy.water.usgs.gov/

This document was prepared by the U.S. Geological Survey (USGS), the Wyoming Department of Agriculture (WDA), and the Wyoming Department of Environmental Quality, Water Quality Division (WDEQ). All agencies are members of the Ground-water and Pesticide Strategy Committee.

This project has been funded in part with a Section 319 grant from the U.S. Environmental Protection Agency to Wyo. Dept. of Environmental Quality's Non-Point Source Program. 